\begin{tabular}{|c|c|c|}
\hline $\begin{array}{l}\text { FATIH } \\
\text { SULTAN } \\
\text { MEHMET } \\
\text { VAKIF UUNIVESIITESI } \\
2010\end{array}$ & $\begin{array}{l}\text { FSM İlmî Araştırmalar Insan ve Toplum Bilimleri Dergisi } \\
\text { FSM Scholarly Studies Journal of Humanities and Social Sciences } \\
\text { Sayı/Number } 14 \text { Yıl/Year } 2019 \text { Güz/Autumn } \\
\text { (C2019 Fatih Sultan Mehmet Vakıf Üniversitesi }\end{array}$ & 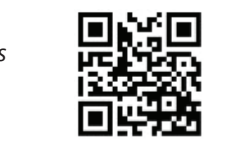 \\
\hline DOI: & http://dergipark.org.tr/fsmia & http://dergi.fsm.edu.tr \\
\hline Araştırma Makalesi / Research Article & Geliş Tarihi / Received: 11.04.2019 Kabul Tarihi / Accepted: 16.05.2019 & FSMIAD, 2019; (14): 327-354 \\
\hline
\end{tabular}

\title{
Şiddeti Yöntem Olarak Benimseyen Radikal Akımların Dikkate Almadığı Fıkhî Kâide: "I'tibâru'l-Meâlât"
}

\author{
Ali Rıza Akgün*
}

\section{Öz}

Günümüz İslam fikhında "i'tibâru'l-meâlât” şeklinde ifade edilen "muhtemel sonuçların dikkate alınması” İslam'da esaslı kâidelerden biridir. İslam’a göre, yapılacak açıklamalarda, verilecek fetvalarda ve ortaya konulacak eylemlerde ortaya çıkacak muhtemel sonuçlar dikkate alınarak hareket edilmesi gerekir. Kur'an ve Sünnet'te dikkate alınması emredilmiş olan i'tibâru'l-meâlât, sahabe döneminden başlayarak tarih boyunca Müslümanların riayet ettiği bir kâidedir. Günümüzde şiddeti yöntem olarak benimseyen radikal akımların sorunlarından biri de şüphesiz i'tibâru'l-meâlât kâidesine uygun hareket etmemesi ve bu kâideyi dikkate almamasıdır. Söz konusu akımlar, eylemlerinde ve söylemlerinde muhtemel sonuçları dikkate almadıkları için İslam Dünyası'nda büyük problemlere sebebiyet vermiş, Müslümanların başına büyük dertler açmışlardır. Afganistan, Irak ve Suriye başta olmak üzere İslam Dünyası'nın birçok yerinde binlerce insanın ölmesine, sakat kalmasına ve kentlerin harap olmasına yol açmışlardır.

Anahtar Kelimeler: F1khî kâide, i'tibâru'l-meâlât, muhtemel sonuçlar, radikal akımlar, şiddet.

* Doktora Öğrencisi, Fatih Sultan Mehmet Vakıf Üniversitesi Lisansüstü Eğitim Enstitüsü Temel İslam Bilimleri, İstanbul/Türkiye, alirizah@hotmail.com, orcid.org/0000-0003-1663-9987 


\title{
The Radical Movement of Adopting Violence as a Method and Not Taking into Account the Juristic Principle: Considering the Possiblitity of the Consequences "I'tibāru'I-Maālāt"
}

\begin{abstract}
In today's Islamic jurisprudence expressing to consider the possible consequences (i'tibāru'l-maālāt) is a vital and essential principle of Islam. According to Islam, statements to be made, fatwas to be given and the actions to be taken necessitate the possible consequences of it to be taking into account. The Quran and Sunnah orders taking into account i'tibāru'l-maālāt, starting with the companions period Muslims throughout history have always abided by this principle. Without a doubt one of the problems with radical movements adopting violence as a method is due to not taking into account the i'tibāru'l-maālāt principle. The relevant movements not taking into account the possible consequences in their actions and words have resulted the Muslim world to face major problems and Muslim individuals to experience troubles. This has resulted many places of the Muslim world particularly Afghanistan, Iraq and Syria to witness thousands of people to die, get afflicted with disability and cities to perish. This study will examine this problem in respect of i'tibāru'l-maālāt.
\end{abstract}

Keywords: Islamic juristic principle, i'tibāru'l-maālāt, possible consequences, radical movement, violence. 


\section{Giriş}

Akıllı bir varlık olan insanın en önemli özelliklerden biri, sadece dış görünüşle yetinmeyip olayların iç yüzünü ve akıbetini idrak ederek karar verebilme kabiliyetine sahip olmasıdır. İnsanda bu kabiliyeti yaratan Yüce Allah, Müslümanlara bu kabiliyetlerini kullanmalarını, söylemlerinde ve eylemlerinde muhtemel sonuçları dikkate alarak hareket etmelerini emretmiştir. ${ }^{1}$ Günümüz İslam fikhında "i'tibâru'l-meâlât" şeklinde ifade edilen "muhtemel sonuçların dikkate alınması" söylenecek sözlerde, verilecek fetvalarda ve ortaya konulacak eylemlerde riayet edilmesi gereken önemli bir kâidedir. Buna binaen herhangi bir şey hakkında bir görüş belirtmeden, bir fetva vermeden ve bir eylem ortaya koymadan önce, ortaya çıkacak muhtemel sonuçlar dikkate alınmalı ve ona göre hareket edilmelidir. ${ }^{2}$ İslam'da muhtemel sonuçların dikkate alınması meselesi ayet ve hadislerle sabit olup, sahabe döneminden başlayarak İslam tarihi boyunca Müslümanlar tarafindan dikkate alınmış ve ona göre hareket edilmiştir.

I'tibâru'l-meâlât (muhtemel sonuçların dikkate alınması) önemli fikhî bir kâide olmasına rağmen şiddeti yöntem olarak benimseyen radikal akımlar bu kâideyi dikkate almamıştır. 1960'lı yılların ortalarından 1980'li yılların başına kadar Mısır merkezli, 1980'li yılların ortalarından 2000'li yıllara kadar Afganistan merkezli, 2000'den günümüze kadar Irak ve Suriye merkezli faaliyet gösteren söz konusu akımlar söylemlerinde ve eylemlerinde muhtemel sonuçları dikkate alarak hareket etmemiştir. Bu akımlara göre Allah yolunda mücadele veriyor olmak ve Müslümanların faydası ve maslahatı için çalışmak meşruiyet için yeterlidir. ${ }^{3}$ Söz konusu akımların Mısır'daki öncülerinden olan Muhammed Abdüsselam Ferac bunların manifestosu mahiyetindeki el-Farîdatu'l-ğaibe adlı risalesinde konuyla ilgili olarak şunları ifade etmiştir: "Bir eylemin meşruiyeti muhtemel sonuçlarıyla irtibatlandırılamaz. Çünkü sonuçlar Allah'ın elindedir ve Allah sonuçları dilediği şekilde yaratır.",

$\mathrm{Bu}$ akımlarda mevcut olan anlayışa göre, Allah için olduğu müddetçe ve Müslümanların faydası düşünülerek ortaya konulan söylemler ve eylemler muhtemel olumsuz sonuçları düşünülerek terk edilemeyeceği gibi, muhtemel sonuçlar üzerine fazla kafa yormaya gerek de yoktur. İyi niyetle yapılan eylemlerin

1 Bakara, 2/205; Rûm, 30/41.

2 Şâtıbî, Ebû İshak İbrahim b. Musa el-Lahmî, el-Muvâfakât fî̀ usûli'ş-şeria, thk. Abdullah Dirâz, c. IV, Beyrut, Dâru'l-mârife, 2008, s. 194.

3 Kumeyl et-Tavîl, el-Kâide ve ehevâtuha, Beyrut, Dâru's-sâkî, 2007, s.73.

4 Muhammed Abdusselem Ferac, el-Farîdatu'l-ğaibe, s. 19-20, http://www.alwahabiyah.com/ file/Occation/vijename/T-K55-ar.pdf , (Erişim tarihi, 3. 10. 2019) 
sonucunda bir takım olumsuzluklar ortaya çıktığı takdirde Müslümana düşen bu sonuca katlanmaktır. Çünkü Allah yolunda gerektiğinde candan, maldan ve vatandan feragat etmek İslam'ın emridir. ${ }^{5}$ Biz bu çalışmamızda öncelikle i'tibâru'l-meâlât kâidesinden ne kastedildiğini, İslam'daki yerinin ne olduğunu, şiddet yanlısı bu akımların tarihsel gelişim sürecini ve 1960'lı yılların ortalarından günümüze kadar sonuçları dikkate almaksızın ortaya koydukları söylemlerle ve eylemlerle İslam Dünyası'na ve Müslümanlara ne gibi zararlar verdiklerini ana hatlarıyla ele alacağız.

\section{1. İ'tibâru'l-meâlâtın Anlamı ve İ́slam'daki Yeri}

İki kelimeden oluşan "i'tibâru'l-meâlât" terkibindeki (izafet terkibi) "itibar" kelimesi mastar olup lügatte, dikkate almak, göz önünde bulundurmak ve hesaba katmak anlamlarına gelir. "Meâlât" kelimesi ise meâl kelimesinin çoğulu olup lügatte, bir şeyin akıbeti, sonucu ve dönüp dolaşıp vardığı yer anlamındadır. İ'tibar ve meâlât kelimelerinin bir araya getirilmesiyle oluşan terkibin kavramsal anlamıyla ilgili olarak da şunları söyleyebiliriz: Kadim ulema i‘tibâru'l-meâlât lafzıyla bir fikhî kâide kullanmamıştır. Ancak i'tibâru'l-meâlâtın mana ve maksadını ifade eden birden çok farklı fikhî kaideler kullanmışlardır. I'tibaru'l-meâlât tabiri bir kavram olarak çağdaş âlimler ve araştırmacılar tarafından kullanılmış olup, "i'tibâr" ve "meâlât" kelimelerinin lügat manaları göz önüne alınarak, "Yapılacak açıklamalar$\mathrm{da}$, verilecek fetvalarda ve ortaya konulacak eylemlerde ortaya çıkması muhtemel sonuçların dikkate alınması ve İslam'ın onaylamadığ 1 sonuçlar söz konusu olduğunda o şeyin terk edilmesi gerektiği” şeklinde bir tarif yapılmıştır. ${ }^{8}$ Bir açıklama yaparken, bir fetva verirken, ya da bir eylem ortaya koyarken muhtemel sonuçların (i‘tibâru'l-meâlât) dikkate alınmasıyla ilgili Kur'an ve Sünnet’te birçok delil mevcuttur. Bu delillere binaen Müslümanların ilk nesli sahabe başta olmak üzere İslam tarihi boyunca âlimler verdikleri fetvalarda ve yaptıkları açıklamalarında ortaya çıkabilecek sonuçları dikkate almış, konunun önemine vurgu yapmış ve sonuçların dikkate alınmasıyla ilgili çeşitli fikhî kâideler ortaya koymuşlardır. ${ }^{9}$

5 Fuad Hüseyin, Zerkavî el-Kâide'nin İkinci Kuşağı, trc. Defne Bayrak, İstanbul, Küresel Yayınlar1, 2014, s.77.

6 İbn Manzûr, Ebu'l-Fazl Cemâluddîn Muhammed b. Mükerrem el-İfrîkî, Lisânu'l-Arab, c. IV, Beyrut, Dâru Sâdır, t.y., s. 531; el-Feyyûmî, Ahmed b. Muhammed b. Ali, el-Misbâhu'l-münîr, Beyrut, Mektebetü Lübnan, 1990, s. 148.

7 İbn Fâris, Ebu'l-Hüseyn Ahmed b. Fâris, Mu 'cemu mekâyîsi'l-luğa, thk. Abdüsselam Muhammed Harun, c. I, Kahire, Dâru'l-fikr, 1979, s. 162; İbn Manzûr, Lisânu'l-Arab, c. XI, s. 32.

8 Ahmed er-Reysûnî, Cemal Bârût, el-İçtihad, Dımeşk, Dâru'l-fikr, 2000, s. 67; Ferîd el-Ensârî, el-Mustalahu'l-usûlî, Virjinya, el-Mâ‘hadu'l-Âlemî li'l-Fikri'l-İ̀lâmî, 2004, s. 457.

9 Ahmed Mer'î Hasan, Fikhu't-tenzîl, Beyrut, Merkezu Nemâ li’l-buhûsi ve'd-dirâsât, 2015, s. 240. 


\section{Muhtemel Sonuçların Dikkate Alınması Gerektiğini İfade Eden Bazı Âyetler:}

Allah Teâlâ, hadd-i zatında şirke vesilesi olan putlarla ilgili, "Onların Allah'ın dışında yalvardıklarına (putlarına) sövmeyin. (Eğer söverseniz) Onlar da haddi aşarak ve cahilce Allah'a söverler"10 buyurarak putlara sövmeyi ve onlar hakkında kötü ve çirkin bir üslupla konuşmayı yasaklamıştır. Çünkü putlar hakkında çirkin ve kötü bir üslupla konuşmak, Mekke Müşriklerinin putlarını savunma adına Allah hakkında kötü ve çirkin konuşma ihtimalini beraberinde getirebilirdi. Dolayısıyla yasak, bizzat putlar hakkında kötü konuşmanın kendisinden değil, bu kötü konuşmanın doğuracağı muhtemel sonuçlardan kaynaklanmıştır. Müfessir Kadı Abdullah b. Ömer Beyzâvî (ö. 685/1286) yukarıda meali verilen ayetin tefsirinde, bizzat günahın terk edilmesi gerektiği gibi, günaha yol açacak olan şeylerin de terk edilmesi gerektiğini ifade etmiş ve bir şeyin kötü ve yasak oluşunun sonuçlarla da alakalı olabileceğini ifade etmiştir. ${ }^{11}$

İhtiyaca binaen çok eşliliği caiz kılan Allah, “... Eğer adaleti uygulayamamaktan korkarsanız bir tane alın yahut sahip olduğunuz (cariyeler) ile yetinin. $\mathrm{Bu}$, adaletten ayrılmamanız için en uygun yoldur" buyurarak, ${ }^{12}$ çok eşlilik durumunda eşler arasında adaleti ikame edememe gibi bir sonucun ortaya çıkma ihtimali olduğunda tek eşle yetinmeyi emretmiştir. İbn Kayyım el-Cevziyye (ö. 751/1350) bu âyette çok eşlilik sonucu oluşma ihtimali olan adaleti ikame edememe sorunu üzerine hüküm bina edildiğini ve çok eşlilikten kaçınılması gerektiğini söylemiştir. ${ }^{13}$

İlk bakışta bir mahzur yokmuş gibi görünen, ancak cevabı açıklandığında (sonuçları itibariyle) bazı kişilerin hoşuna gitmeyecek gerçeklerin ortaya çıkmasina sebep olma ihtimali olan soruların Hz. Peygamber'e sorulmasıyla ilgili Allah Teâlâ şöyle buyurmuştur: "Ey iman edenler! Açıklandığında hoşunuza gitmeyecek olan şeyler hakkında (Peygamber'e) soru sormayın. Kur'an indirilirken onlar hakkında soru sorarsanız size (gerçek) açıklanır. (Size bildirilmediğine göre) Allah onları affetmiştir. (Siz sorup da başınıza iş çıkarmayın) Allah çok bağışlayıcıdır, aceleci değildir." ${ }^{14}$ Normalde Peygamber'e soru sormak caiz olduğu

10 En'am, 6/108.

11 Beyzâvî, Nâsiruddîn Ebû Saîd Abdullah b. Ömer, Envâru't-tenzîl ve esrâru't-tevîl, c. II, Beyrut, Dâru ihyâi't-turâsi'l-Arabî, t.y., s. 177.

12 Nisa, $4 / 3$.

13 İbn Kayyım el-Cevziyye, Muhammed b. Ebî Bekir, I' 'lâmu'l-muvakklîn an Rabbi'l-âlemîn, c. III, Kahire, Mektebetü'l-külliyyâti'l-ezheriyye, 1968, s. 169.

14 Mâide, 5101/. 
halde, ortaya kötü bir sonuç çıkma ihtimali olduğu durumlarda Müslümanların Peygamber'e soru sormaları yasaklamıştır. Buradaki yasak soru sormanın kendisiyle alakalı olmayıp, ortaya çıkabilecek muhtemel kötü sonuçlar sebebiyledir. ${ }^{15}$ Muhtemel sonuçların dikkate alınmasıyla ilgili başka ayetler de vardır. Ancak konuyu fazla uzatmamak için burada örnek mahiyetinde zikrettiğimiz bu üç ayetle yetiniyoruz.

\section{Muhtemel Sonuçların Dikkate Alınması Gerektiğini İfade Eden Bazı Hadisler:}

Yapılacak açıklamalarda ve ortaya konulacak eylemlerde muhtemel sonuçların dikkate alınması meselesi Hz. Peygamber'in davete başladığı ilk günden itibaren en çok önem verdiği konulardan biriydi. O, gerek Müslümanların zayıf konumda oldukları Mekke Dönemi'nde, gerekse güçlü oldukları Medine Dönemi'nde İslam'ın yükselişine zarar verme ihtimali olan eylem ve söylemlere asla müsaade etmemiştir. Mekkeli müşriklerin onca eziyetlerine rağmen ${ }^{16}$ Müslümanlara sabır ve tahammülü tavsiye etmiş, zayıf durumdaki Müslümanların kuvvetli durumdaki müşriklerle çatışmasına ve vahim sonuçların ortaya çıkmasına asla müsaade etmemiştir. ${ }^{17}$ Aynı şekilde Müslümanların güçlü oldukları dönemlerde de olgunluğu elden bırakmayan Hz. Peygamber, sonuçları itibariyle İslam'ın ve Müslümanların aleyhlerine olabilecek eylemlerden ve söylemlerden sakındırmıştır. ${ }^{18}$

Bir gün Hz. Peygamber ile Hz. Aişe arasında Kâbe'nin mevcut binası ilgili bir konuşma geçer. Efendimiz bu konuşmada, "Kâbe'nin İbrahim Peygamberin attığ temellerden içeriye çekilerek inşa edilip onarıldığını ve bundan kendisinin hoşnut olmadığını" dile getirir. Aişe, "Ya Resûlallah Kâbe'yi İbrahim Peygamberin temelleri üzerine yeniden yapmayacak misın?" der. Bunun üzerine Hz. Peygamber, "Kavmin küfürden henüz yeni çıkmış olmasaydı (o şekilde) yapardım" buyurur. ${ }^{19}$ Hz. Peygamber burada bir fayda-zarar (maslahat-mefsedet) kıyaslaması yapmış ve Müslümanlar açısından ortaya çıkma ihtimali olan bir zararı (mefsedet) dikkate almış ve onu def etme adına gönlünün istediği faydayı (maslahat) terk etmiştir.

15 Abdurrahman b. Muammer es-Senûsî, I'tibâru'l-meâlât ve murââtu netâici't-tasarrufât, Riyad, Dâru İbni'l-Cevzî, 2003, s. 128.

16 İbn Hişâm, es-Sîretu'n-Nebeviyye, c. I, Kahire, Dâru ihyâi'l-kütübi'l-Arabiyye, t.y., s. 199222; İbn Kesîr, Ebu'l-fidâ, el-Bidâye ve'n-nihâye, c. II, Kahire, Dâru'l-hadîs, 1997, s. 95-103.

17 Buharî, Ebû Abdillah Muhammed b. İsmail, Sahîhu'l-Buharî, Dâru Tavkıın-necât, b.y.y., h., 1422, Menâkıp, 22; Nesâî, Ebû Abdurrahman Ahmed b. Şuayb el- Horasânî, Sünenü'n-Nesâî, Mektebetu Matbuatu'l-islamiyye, 2. bs., b.y.y., 1986, Cihat, 1.

18 Ebû Şehbe, Muhammed b. Muhammed, es-Sîretu'n-Nebeviyye fí dav'il-Kur'ani ve 's-Sünne, c. II, Dımeşk, Dâru'l-kalem, s 1992,. 448.

19 Buhari, Hacc, 42. 
Yalan söylemek İslam'da büyük günahlardan ve kötü hasletlerden sayılmıştır. Hz. Peygamber bir Müslümanın çeşitli hatalar yapabileceğini ancak asla yalan söyleyemeyeceğini ifade etmiştir. ${ }^{20}$ Ancak yalan konusunda bu derece titiz olan Rasûlullah savaşta, insanların arasını bulmak için ve karı-koca arasındaki geçimsizliği gidermek amaçlı yalan söylemeye cevaz ve ruhsat vermiştir. ${ }^{21}$ Meşhur Şâfiî fakihi İzzeddin b. Abdüsselam (ö. 660/1262) yalan söylemekle ilgili olarak, "Yalan aslı itibariyle kötü ve kesin haramdır. Ancak sonucu itibariyle önemli bir faydayı celp edip, önemli bir zararı def ediyorsa bu durumda yalan söylemek bazen caiz, bazen de vacip olur" demiştir. ${ }^{22}$

Hz. Peygamber bir gün Muaz’a, “Ey Muaz! Allah'ın kulları üzerindeki hakkının ne olduğunu ve kulların Allah üzerindeki hakkının ne olduğunu bilir misin?” dedi. Muaz, "Allah ve Rasûlu daha iyi bilir" deyince Rasûlullah, "Allah'ın kullar üzerindeki hakkı ona ibadet/kulluk etmeleri ve ona şirk koşmamalarıdır. Kulların Allah üzerindeki hakkı ise kendisine şirk koşmayana azap etmemesidir" buyurdu. Bunun üzerine Muaz, "Ey Allah'ın Rasûlu bu müjdeyi insanlara bildireyim mi?" dedi. Rasûlullah, "Hayır bildirme! Tembellik ederler" buyurdu. ${ }^{23}$ Rasûlullah'ın açıkça ifade ettiği bu müjdeyi Muaz'ın insanlara haber vermesinde aslı itibariyle bir beis yoktu. Ancak Rasûlullah, bu haberin insanlara ulaşmasıyla ortaya çıkma ihtimali olan olumsuzluğu yani tembelliği dikkate almış ve bu müjdenin insanlara ulaşmasını engellemeyi uygun görmüştü. ${ }^{24}$ Burada zikrettiğimiz örneklerin dışında, Resûlullah'ın söylemlerinde ve uygulamalarında muhtemel sonuçları dikkate aldığına dair birçok örnek vardır. Hatta o bütün bir İslami tebliğ hayatında sonuçları dikkate alarak hareket etmiştir, diyebiliriz.

\section{Muhtemel Sonuçların Dikkate Alındığı Bazı Sahabe Fetvaları:}

Hz. Ömer, Yemen-San'a'da bir kişiyi ortaklaşa öldüren bir grup insanı, öldürdükleri kişiye karşılık kısas yaptırmış ve "Bütün Sana ehli bu suça ortak olsaydı hepsine kısas uygulardım” demiştir. ${ }^{25} \mathrm{~Hz}$. Ömer işin varacağı sonucu göz önüne

20 Malik b. Enes el-Medenî, Muvatta, thk. Muhammed Mustafa el-A'zamî, Müessesetü Zayid b. Sultan, Ebû Zabiy, 2004, Kelâm, 7.

21 Müslim, Ebû'l-Hasen b. el-Haccac en-Nîysâbûrî: Sahih'u Müslim, thk. M. Fuat Abdulbakî, Beyrut, Dâru ihyau't turasil-Arabî, t.y., el-Birr ve's-S1la ve'l-Âdâb, 27.

22 İzzeddin b. Abdusselam, Ebû Muhammed, Kavâi 'du'l-ahkam fî mesâlihi'l-enâm, c. 1, Beyrut, Dâru'l-meârif, t.y., s. 112.

23 Buhari, Cihad, 46.

24 Hz. Muaz, Resûlullah’tan duyduğu bir şeyi gizleyerek ölmekten korktuğu için ölmeden önce bu hadisi rivayet etmiştir. Bkz. Saduddîn el-Osmânî, Flkhu'l-meâlât mefhûmuhû ve kavâiduhû, Kahire, Dâru'l-kelim, 2015, s.32.

25 Muvatta, el-U‘kûl, 19. 
alarak bu tür bir cezayı öngörmüş ve sert bir önlem almıştır. Çünkü bu tür bir suçun önü alınmadığı takdirde, insanlar cinayetleri (insan öldürmeyi) toplu halde işleyerek cezadan kurtulma yoluna gitmeleri söz konusu olur. Hz. Ömer San'a'da işlenen bu cinayeti sonuçları (meâlât) itibariyle ele almış ve ona göre bir hüküm vermiştir. $^{26}$

Hz. Ömer hilafeti döneminde, Müslüman erkeklerin (gazilerin) yeni fethedilen yerlerde Ehl-i kitap kadınlarla evlenmelerini yasaklamıştır. ${ }^{27}$ Şüphesiz bu yasak aslı itibariyle ve daimi bir yasak olmayıp, Müslüman bekâr kadınların İslam toplumunda çoğalmasıyla oluşma ihtimali olan bir problemin önüne geçmek gayesiyle konulmuş siyasi içerikli bir yasaktır. Hz. Ömer bu yasağı, Ehl-i kitap kadınlarla evlenme sonucu ortaya çıkma ihtimali olan olumsuz sonuçlara bağlı olarak ve devlet başkanı olma sıfatıyla yürürlüğe koymuştur. Dolaysıyla olumsuz sonuçların ortadan kalkmasıyla bu tür yasaklarda ortadan kalkar. ${ }^{28}$

Hz. Ali İslâmî eğitimde bazı insanların uygun üslubu kullanmadığını görünce, “İnsanlara akılları ölçüsünde konuşun, Allah'ın ve O'nun elçisinin yalanlanmasını ister misiniz!?” buyurmuştur. ${ }^{29} \mathrm{~Hz}$. Ali burada insanlara anlamayacakları bir üslupla hitap edildiğinde ortaya ne gibi tehlikeli sonuçların çıkabileceğine dikkat çekmiş ve bu olumsuz sonuçla karşılaşmamak için baştan önlem alınması gerektiğini ifade etmiştir. Bu konuda İbn Mes'ud'tan da benzer bir uyarı söz konusudur. ${ }^{30}$

Abdullah b. Abbas'a bir gün bir adam geldi ve "Kasten bir Müslümanı öldüren kimsenin tövbesi kabul olur mu?" dedi. İbn Abbas, "Hayır tövbesi kabul olmaz. O kişi cehennemliktir" dedi. Adam gidince İbn Abbas'ın yanındakiler, "Sen bize daha önce, katilin tövbesi kabul olur şeklinde fetva vermiştin" deyince, İbn Abbas onlara, "Ben o adamın kızgın olduğunu gördüm ve gidip birini öldüreceğini tahmin ettiğim için ona öyle fetva verdim" dedi. O adamı araştırdıklarında İbn Abbas' 1 tahmininde isabet ettiğini tespit ettiler. ${ }^{31}$ İbn Abbas burada oluşabilecek muhtemel sonucu dikkate almış ve ona göre fetva vererek oluşma ihtimali olan bir zararı ve mefsedeti ortadan kaldırmıştır.

26 Yusuf b. Abdullah Ahmeytu, Mebdeu i 'tibâri'l-meâl fi'l-bahsi'l-fikhî, Beyrut, Merkezu Nemâ li'l-buhûsi ve'd-dirâsât, 2012, s. 69-70.

27 Osmânî, a.g.e., s. 36.

28 Osmânî, a.g.e., s. 36.

29 Buharî, Sahih, İlim, 50.

30 Osmânî, a.g.e., s. 34.

31 İbn Ebî Şeybe, Musannef, thk. Muhammed Avvâme, c. XIV, Cidde, Dâru'l-kıble, 2006, s. 249. 
Sahabe döneminde sonuçlar dikkate alınarak gerçekleştirilen önemli içtihatlardan ve uygulamalardan biri de şüphesiz Hz. Hasan'ın hilafeti Muaviye b. Ebî Süfyan'a bırakmasıdır. Hz. Hasan bu uygulamasıyla şüphesiz ümmetin maslahatını düşünmüş, akan Müslüman kanını durdurmak ve Müslümanların birliğini sağlamak gibi çok önemli bir sonuca ulaşmayı hedeflemiştir. Hz. Hasan'ın bu içtihadı ve uygulaması güzel netice vermiş, Müslümanlar sevinerek o y1lı "Cemaat (birlik-beraberlik) Yılı" ilan etmişlerdir. ${ }^{32}$

\section{2. Âlimlerin İ‘tibâru'l-meâlât Konusuna Yaklaşımı}

Dört mezhep imamı başta olma üzere İslam tarihi boyunca âlimler i'tibâru'l-meâlâtı (muhtemel sonuçları) dikkate almış, fetvalarında ve açıklamalarında bu ilkeye riayet etmişlerdir. Meseleleri muhtemel sonuçlarına göre ele almış, yaptıkları araştırma ve inceleme sonucu eğer o iş sonuçları itibariyle faydalı ise olumlu, sonuçları itibariyle zararlı ise olumsuz görüş beyan etmişlerdir. ${ }^{33}$ Sonuçların dikkate alınması meselesini doğrudan dile getiren âlimlerden biri meşhur Mâlikî fakihi Şâtıbî’ (ö. 790/1388) dir. Şâtıbî ortaya çıkması muhtemel sonuçların dikkate alınmasıyla ilgili şöyle der: "Ortaya çıkacak sonuçların dikkate alınması şeriatın emridir. Yapılacak işlerde ortaya çıkacak sonuç maslahata uygun ve faydalı ise o şey yapılmalı, faydalı değil ise o şey terk edilmelidir."34 Şâtibî burada, İslam'a göre bir şeyin yapılabilmesi için sadece yapıldığı anda doğru ve meşru olmasının yeterli olmadığını, sonuçları itibariyle de maslahata uygun ve faydalı olması gerektiğini ifade etmiştir. Sahabe döneminden başlayarak sonuçların dikkate alınması meselesine önem veren âlimler konunun önemine binaen birtakım fikhî kaideler koymuşlar, meseleyi formülize etmişlerdir. O kaidelerden bazıları şunlardır: "Bir şeyin helal veya haram olması, o şeyin sonucu itibariyledir.", "İşler akıbetlerine göre değerlendirilir.", "Gerçekleşmesi beklenen, hükmen gerçekleşmiş gibidir.", "Gelecekte vaki olacak zarar, şimdi vaki olmuş gibidir." ${ }^{35}$ Şüphesiz İslam fikhında karar kı1mış olan bu kâideler âlimlerin konuya ne denli önem verdiklerini ortaya koymaktadır.

Çağdaş âlimlerden Yusuf el-Karadâvî de, İslam tarihi boyunca âlimlerin bireyleri ilgilendiren meselelerde olduğu gibi, toplumu ilgilendiren meselelerde de sonuçları dikkate aldıklarını ifade etmiş ve toplumu ilgilendiren meselelerde sonuçların dikkate alınmasının çok daha önemli olduğuna vurgu yapmıştır. ${ }^{36}$ Çünkü

32 İbn Kesîr, a.g.e., c. IX, s. 210.

33 Geniş bilgi için bkz. Ahmed Mer‘î Hasan, a.g.e., s. 263-274.

34 Şâtıbî, a.g.e., c. IV, s. 194.

35 Geniş bilgi için bkz. Osmânî, a.g.e., s.12; Ahmeytu, a.g.e., s.38.

36 Geniş bilgi için bkz. Yusuf el-Karadâvî, Flkhu'l-cihâd dirase mukârene li ahkâmihi ve felsefetihi fì dav'i'l-Kur'ani ve's-Sünne, 3. bs., Kahire, Mektebetu Vehbe, 2009, s. 96-97. 
toplumu ilgilendiren meseleler bireyleri ilgilendiren meselelerden daha ehemmiyetlidir. Sonuçların dikkate alınmasının önemine binaen günümüzde Müslüman toplumlara yönelik çalışma yapan, proje ortaya koyan ve cihad ettiğini söyleyen cemaatlerin ve akımların çok daha dikkatli olmaları, söylemlerinde ve eylemlerinde muhtemel sonuçları dikkate alarak hareket etmeleri gerekmektedir. Muhtemel sonuçlar dikkate alınmadan hareket edilerek, Müslüman toplumun can, mal, 1rz, toprak ve benzeri konulardaki emniyetlerine gelecek herhangi bir zararın veya olumsuzluğun Allah katındaki sorumluluğu şüphesiz ağır olacaktır. Uluslararası sistemin toplumsal hareketleri takip ettiği ve kendi çıkarları doğrultusunda kullanmak istediği günümüzde, Müslümanların faydasına olacak şeyleri ortaya koymak için çalışma yaptığını, cihat ettiğini söyleyen cemaat, cemiyet ve akımların sadece sonuçları dikkate aldığını iddia etmesi yeterli değildir. Bu iddianın yanı sıra muhtemel sonuçları tespit edebilmek için gerekli bilgi ve birikime sahip olmaları gerekmektedir. Muhtemel sonuçları dikkate almak ve ona göre hareket etmek özellikle Müslümanların zayıf oldukları dönemlerde daha bir önem arz etmektedir.

\section{3. Şiddet Yanlısı Akımların Tarihi Süreci ve İ‘tibaru’l-meâlâta Bakışı}

Günümüzde şiddeti yöntem olarak benimseyen radikal akımların tarihi süreci Misır, Afganistan, Irak ve Suriye merkezli olmak üzere üç dönemden oluşmaktadır. Mısır dönemi, şiddet düşüncesinin ilk oluştuğu 1960'lı yılların sonlarından 1980'li yılların ortalarına kadardır. Afganistan dönemi, akımın düşünce dünyasının gelişip teolojik alt yapısının tamamlandığı 1980'li yılların ortalarından 2000'li yıllara kadardır. Irak ve Suriye dönemi ise, aşırılık ve şiddet düşüncesinin bariz bir şekilde uygulandığı 2000'li yıllardan günümüze kadar olan süreçtir. Şiddet yanlısı bu akımların tarihi sürecini ele almaktaki amacımız, bu akımların bu süreç içerisinde sonuçları dikkate almayarak gerçekleştirdikleri söylemlerle ve eylemlerle Müslümanlara ve İslam Dünyası'na verdikleri zarara işaret etmektir.

\section{1. Şiddet Yanlısı Radikal Akımların Mısır'da Ortaya Çıkışı}

Şiddet yanlısı radikal akımların tarihî serüvenlerine ve sonuçları dikkate alma meselesine bakışlarına girmeden önce, bu akımların Mısır merkezli ortaya çıkışlarına ve bu ortaya çıkışı hazırlayan sebeplere kısaca değinmemiz uygun olacaktır. Bu akımların oluşumunu hazırlayan sebepler Osmanlı sonrası İslam Dünyası'nda oluşan siyasî ve sosyal ortama kadar uzanmaktadır. Osmanlı İmparatorluğu»nun tasfiyesi ve hilafetin ilgasının ardından uluslararası boyuttaki siyasî güçlerini kaybeden Müslümanlar ciddi bir sarsıntı yaşadılar. Bu dönemde İslam coğrafyasında kurulan ulus devletlerin İslâmî değerlerden uzaklaşarak Batılı değerleri 
benimseyen bir tavır içerisine girmesi Müslüman halkların endişesini daha da artırdı. ${ }^{37}$ Batı yanlısı rejimlerin anlayış ve uygulamalarından hoşnut olmayan bazı dindar çevreler bulundukları coğrafyalarda İslâmî bir düzen kurmak ve hilafeti yeniden ihya etmek amacıyla bir takım çalışmalar başlattılar. Bu çalışmalar zamanla İslam Dünyası'nın çeşitli yerlerinde İslâmî hareketlerin ortaya çıkmasını beraberinde getirdi. ${ }^{38}$ Oluşan İslâmî hareketlerden biri de Mısır'da ortaya çıkan İhvan-1 Müslimîn (Müslüman Kardeşler) hareketiydi. ${ }^{39}$ Misır merkezli başlayan İhvan hareketi fikriyatı, söylemleri ve çalışmalarıyla dikkat çekerek İslam Dünyası’ndaki diğer İslâmî çalışmaları etkiledi ve merkezî bir konuma yükseldi. ${ }^{40}$

1928'de Misır-İsmailiyye'de Hasan el-Bennâ (ö. 1949) tarafindan kurulan ve çalışmalarına İsmailiyye'de başlayan İhvan hareketi kısa sürede büyüdü ve 1932'de yönetim merkezini Kahire'ye taşıdı. 1940'lı yıllara gelindiğinde cemaatin Mısır sathında şube sayısı binlere, üye sayısı ise yüz binlere ulaşmışı $1{ }^{41}$ Mısır dışında Suriye, Filistin, Ürdün, Lübnan, Irak, Yemen ve Sudan gibi çevre ülkelerde de kısa sürede yayılmaya başlayan İhvan, İngilizler başta olmak üzere bölgedeki Batılı güçleri ve Batı yanlısı rejimleri rahatsız etmeye başladı ${ }^{42} \mathrm{O}$ tarihlerde Misır'da hüküm süren (1952'ye kadar) Kral Faruk rejimi İhvan üzerindeki baskısını artırdı ve 8 Aralık 1948'de İhvan'ın tamamen yasaklandığını ilan etti. Hareketin tüm mal varlığına el konuldu ve önde gelen liderleri tutuklandı. ${ }^{43} \mathrm{Bu}$ olay üzerinden henüz iki ay geçmişti ki, hareketin kurucu lideri Hasan el-Bennâ Kahire'de uğradığı bir silahlı saldırı sonucu 12 Şubat 1949'da hayatını kaybetti. ${ }^{44}$ İçeride kraliyet rejiminin İhvan'a vurduğu darbe ve cemaatin kurucu lideri Hasan el-Bennâ'nın öldürülmesi, dışarıda ise, 15 Mayıs 1948>de Arap devletlerinin gözü önünde İsrail Devleti'nin kurulması ve birçok ülke tarafından tanınması hare-

37 Halil Aydınalp, "İslam Dünyasında Siyasi Şiddetin Sosyolojik Unsurları”, Din ve Şiddet, Recep Tayyip Erdoğan Üniversitesi, Ankara, Kalkan Matbaacılık, 2016, s. 212.

38 S. Sayyid, Fundamentalizm Korkusu, trc. Ebubekir Ceylan, Nuh Y1lmaz, Şükrü Atsızelti, İstanbul, Aç1lım kitap, 2017, s.67.

39 Üsame Sa‘d, Eşref Iyd el-Anteblî, "Mukaddime” et-Tarîhu'ş-şamil li’l-İhvani'l-Müslimin, İstanbul, Dâru Nida, 2017, s. 4; Ahmet Salim, İhtilâfùl-İslâmiyyîn, Beyrut, Merkezu Nemâ li'l-buhûsi ve'd-dirâsât 2. bs., 2014, s. 24.

40 Burhanettin Duran - Nuh Yılmaz, “Ortadoğu'da Modellerin Rekabeti: Arap Baharından Sonra Yeni Güç Dengeleri”, Türk Dış Politikası Yıllı̆̆l, SETA Yayınları, 2011, s. 58.

41 Enver el-Cündî, Hasan el-Bennâ, Dımeşk, Dâru'l-kalem, 2000, s. 55.

42 Üsame Sa'd, Eşref Iyd el-Anteblî, "Mukaddime" a.g.e., s. 52.

43 Mâni‘b. Hammâd el-Cühenî, el-Mevsûa'tu'l-müyessere fíl-edyân ve'l-mezâhib ve'l-ahzâbi'l-muâsıra, 3. bs., c. I, Riyad, Dâru'n-Nedveti'l-Âlemiyye, 1997, s. 203.

44 Mahmud Abdulhalîm, el-İhvânu'l-Müslimûn, ehdâs sanaati't-tarîh, c. II, İskenderiyye, Dâru'd-dâ've, t.y, s. 80 . 
ketin özellikle genç kuşağ 1 üzerinde olumsuz etki yaptı ve Mısır rejimine karşı büyük bir tepkinin oluşmasına sebep oldu. ${ }^{45}$

1952 'de ordu içerisindeki bir grup subayın gerçekleştirdiği bir askerî darbe sonucu kraliyet rejimi sona erdi. Ancak başa gelen askerî yönetim kraliyet rejimini aratan uygulamalara imza attı. Askerî yönetimin başını çeken Cemal Abdunnâsır kendisine yönelik yapılan bir suikast girişiminin arkasında İhvan'ın olduğunu iddia ederek 1954 'te hareketi yasa dış1 ilan etti ve bütün şubelerini kapattı. Hareketin tüm mal varlığına el koydu ve lider kadro başta olmak üzere binlerce cemaat mensubunu tutuklattı. ${ }^{46}$ Askerî mahkemelerde yapılan yargılamalar sonucu hareketin önde gelenlerinden altı kişi idam edilirken birçok İhvan mensubu çeşitli cezalara çarptırıldı ${ }^{47}$ Hareketin ön saflarında mücadele vermiş ve yaptıkları hizmetlerle insanların takdirini kazanmış altı kişinin göstermelik bir yargılama sonucu idam edilmesi, hareket içerisinde büyük bir infiale sebep oldu. Yaşanılan bu olumsuz sürece bir de cezaevlerinde uygulanan ağır işkenceler, işkenceler altında insanların arkadaşlarının gözü önünde can vermesi, dışarıda mahkûm ailelerine yönelik uygulanan bask1 ve tehditler eklenince ${ }^{48}$ özellikle gençler arasında bu zulümleri yapan yöneticilerin Müslümanlığ 1 ve rejimin meşruiyeti sorgulanmaya başland ${ }_{1}{ }^{49} \mathrm{Bu}$ süreç devam ederken 1954 'de tutuklanan ve cezaevinde yaklaşık on yıl kalan İhvan liderlerinden Seyyid Kutub iki arkadaşıy$1 a^{50}$ beraber idam edildi. ${ }^{51}$ Rejimin İhvan mensuplarına karşı takındığ düşmanca tavır, şiddet, işkence ve daha önce gerçekleştirdiği infazlara bir de Seyyid Kutub ve arkadaşlarının idamı eklenince bu durum hareket içerisinde adeta bir travmaya sebep oldu. ${ }^{52}$ Bir zaman sonra hareket içerisindeki tartışmalar artık rejimin meşruiyeti ve yöneticilerin Müslümanlığından ziyade, İhvan'1n 1slahatçı anlayışı ve rejime karşı yeterince sert tavır almaması noktasında yoğunlaşmaya başladı. ${ }^{53}$

45 Yusuf el-Karadâvî, el-İhvanu'l-Müslimûn, Kahire, Mektebetu Vehbe, 1999, s. 271-272.

46 Muhammed Hâmid Ebu'n-Nasr, Hakîkatu'l-hilâf beyne'l-İhvâni'l-Müslimîn ve Abdunnâsır, Kahire, Dâru't-tevzi' ve'n-neşri'l-İslâmiyye, 1988, s. 68.

47 İdam edilenler: Abdülkadir Udeh, Muhammed Ferğali, Yusuf Talat, Hindavi Duveyr, İbrahim et-Tayyib ve Mahmud Abdullatif'dir. Bkz. Cühenî, a.g.e., c. I, s. 203.

48 Abdulhalim el-Kennânî, Mevsûa'tu'ş-şuhedâ, Tanta, Dâru'l-beşîr, 1994, s. 33-34.

49 Salih el-Verdânî, Mısır'da İslâmî Akımlar, trc. H. Açar, Ş. Duman, S. Turan, 2. bs., İstanbul, Fecr Yayınlar1, 2011, s. 44-45.

50 Bu iki kişi, Yusuf Havvâş ve Abdulfettah İsmail'dir. Bkz. Ahmed Salim, İhtilâfu〉l-islâmiyyîn, 2. bs., Beyrut, Merkezu Nemâ li'l-buhûsi ve'd-dirâsât, 2014, s. 134.

51 Ahmed Salim, a.g.e., s. 134.

52 Verdânî, a.g.e., s. 44.

53 Verdânî, a.g.e., s. 44. 
1960 'lı yılların ortalarına gelindiğinde rejimin baskısı ve cezaevlerindeki işkenceler sonucu, cezaevlerinde İhvan'ın 1slahatçı anlayışını tamamen reddeden şiddet yanlısı tekfirci bir gençlik oluşmaya başladı. İlerleyen yıllarda "Tekfir ve Hicret Cemaati” ismiyle anılacak olan cezaevlerindeki bu oluşuma paralel olarak, cezaevi dışında da aynı zihniyette grupların oluşmaya başladığı görüldü. M1sır'ın farklı bölgelerinde küçük gruplar halinde oluşmaya başlayan şiddet yanlıları 1970'li yıllara gelindiğinde çoğu birbiriyle irtibat kurdular ve Tanzîmu'l-Cihad (Cihat Örgütü) adıyla organize olarak rejime karşı silahlı eylemlere başladılar..$^{54}$ Tanzîmu'l-Cihad'ın yanı sıra 1970'li yılların başında Mısır'daki çeşitli üniversitelerde davet çalışmalarıyla tanınan el-Cemaatu'l-İslamiyye de rejimin takındığ sert tavır ve cemaat mensuplarına yönelik başlatılan tutuklamalar üzerine 1970'li yılların sonlarına doğru şiddet eğilimine girdi ve rejime karşı silahlı mücadeleye başladı. ${ }^{55}$ Mısır'da şiddet yanlısı akımların başını çeken Tanzîmu'l-Cihad ve el-Cemaatu'l-İslamiyye bazen güç birliği yaparak, bazen de her biri ayrı ayrı çeşitli silahlı eylemler gerçekleştirdiler. Mısırlı yazar Abdulmun`im Munîb'in bildirdiğine göre, "Bu akımların gerek Mısır emniyet güçleriyle girdikleri çatışmalarda gerekse farklı hedeflere düzenledikleri silahlı eylemlerde yüzlerce kişi ölmüş ve yüzlercesi yaralanmıştır." ${ }^{56}$ Mısır Devleti'nin 2000'li yıllara kadar şiddet yanlısı akımlara yönelik gerçekleştirdiği idamlarda 90 kişinin hayatını kaybettiği söylenmektedir. ${ }^{57}$

Silahlı mücadeleyi tek çıkar yol gören şiddet yanlısı akımlar 6 Ekim 1981'de Mısır Cumhurbaşkanı Enver Sedat'1 öldürdüler. Yaşadıkları dönemin şartlarına riayet etmeyen ve gerçekleştirdikleri eylemlerde muhtemel sonuçları dikkate almayan bu akımlar, ${ }^{58}$ Enver Sedat suikastıyla hem kendilerine, hem de İslâmî çalışmalara büyük zarar verdiler. Şiddet yanlısı akımların tarihini yazan Suud el-Mevla’ya göre, "Enver Sedat suikastının akabinde Mısır'daki İslâmî faaliyetler tamamen durma noktasına geldi." Suikast olayına adı karışanlar tutuklanırken, akıma mensup birçok kişi ülke dışına kaçma zorunda kaldı. Ülke dışına kaçanların kahir ekseriyeti Afganistan>daki Afgan-Rus savaşı nedeniyle Afganistan'a gitmeyi tercih etti. ${ }^{59}$

54 Abdulmun'im Munîb, Delîlu'l-harekâti'l-İslâmiyye el-muâsıra, Kahire, Mektebetu'l-medbûlî, 2010, 73-74.

55 Raşid b. Osman ez-Zehrânî, el-Cemaatu'l-cihâdiyye el-muâsıra ve ebrezu kiyâdâtihi'l-fikriyye, Riyad, Dâru Vucûh, 2016, s. 52.

56 Abdulmun'im Munîb, a.g.e., 73-74.

57 https://m.facebook.com/story.php?story_fbid=589713864831004\&id=100013771866578, (Erişim tarihi, 10. 2. 2019)

58 Abdusselem Ferac, a.g.e., s. 19-20.

59 Suud el-Mevlâ, el-Cemââtu'l-İslâmiyye ve'l-unf, Dubai, Merkezu'l-misbâr li'd-dirâsâti ve'lbuhûs, 2012, s. 688 . 
1960'lı yılların sonlarına doğru başlayan şiddet yanlısı akımların Mısır dönemi, 1980'li yılların başında mensuplarının bir kısmının cezaevine girmesiyle, bir kısmının da Afganistan'a intikaliyle sona ermiş oldu. Şiddet yanlısı akımlar Mısır dışında Suriye, Libya, Tunus, Sudan vb. çevre ülkelerde de mevcut olmasına rağmen Mısır, 1960'lı yılların sonlarından 1980'li yılların başlarına kadar bu akımların merkezi konumunda olmuştur. ${ }^{60}$ Daha sonraki yıllarda İslam Dünyası'nda büyük yaralar açacak olan tekfir ve şiddet anlayışının teolojik alt yapısı 1960'lı yılların sonlarından 1980'li yılların başlarına kadar olan dönemde büyük oranda Mısır'da oluşturuldu. O dönem şiddet yanlısı akımlar tarafından kaleme alınan eserler içerisinde en meşhur olanı Muhammed Abdüsselam Ferac'in yazdığı el-Farîdatu'l-ğâibe adlı risaledir. Bu risalede kendileri gibi düşünmeyen Müslüman cemaatlere karşı olumsuz bakışları açıkça ortaya konulmuş ve rejime karşı silahlı mücadelenin kaçınılmazlığ 1 vurgulanmıştır.

\subsection{Afgan-Rus Savaşı ve Şiddet Yanlısı Radikal Akımların Afganistan'da Toplanması}

27 Aralık 1979'da başlayan Afgan-Rus savaşı nedeniyle kendilerine Afganistan ve Pakistan-Peşaver'de yer bulan şiddet yanlısı radikal akımlar 80'li yılların ortalarına doğru o bölgeyi merkez edindi ve Mısır başta olmak üzere İslam Dünyası'nın birçok yerinden giderek orada toplandılar. ${ }^{61}$ Afganistan'a giden şiddet yanlısı akımlar kendi ülkelerinde yaşadıkları süreçten ders çıkartmak ve fikirlerini gözden geçirmek yerine, aşırılık ve şiddet yanlısı anlayışlarını Afganistan'da da devam ettirdiler. Hatta aşırılık ve şiddet yanlısı anlayış Afganistan'da daha da şiddetlendi. Şöyle ki, Arap Yarımadası'ndan Afganistan'a giden zâhirî (lafızcı) bakış açısına sahip Selefîlerle (Vehhâbîler) Mısır merkezli şiddet yanlısı akımlar Afganistan'da buluşarak birbirinden etkilendi ve daha şedid bir anlayış ortaya çıtı. 1980'li yılların başında Afganistan'a ilk giden Mısırlılardan Mustafa Hamid'in bildirdiğine göre, "Radikal akımlara mensup insanların kahir ekseriyeti, mutasavvıf ve Eş'arî oldukları gerekçesiyle Afganistanlı mücahitleri sapıklıkla itham etmiş ve onlarla aynı safta cihat etmekten kaçınmışlar. Hatta bazıları Afganları müşrik gördüğü için Afgan imamların arkasında namaz dahi kılmamışlar."

Bu akımlar Mısır döneminde olduğu gibi Afganistan'da da geleceği dikkate alarak bir tasavvur ortaya koymamış, İslam'ın öngördüğü birlik-beraberlik ilkesine riayet ederek Müslümanlar arasındaki ihtilafları azaltma yoluna gitmemişler-

60 Burhanettin Duran - Nuh Y1lmaz, a.g.m., s. 58.

61 Muhammed Allûş, Dâiş ve ehavâtuhâ, Beyrut, Riyâdu'r-reyyis li'l-kütüb ve'n-neşr, 2015, s. 28.

62 Mustafa Hamid, Lia Varal, el-Arap fì harbi Afganistan, Büyük Biritanya, Dâru Heyrest, 2015, s.117. 
dir. Hakikati sadece kendilerinin temsil ettiği inancıyla hareket ederek, kendileri gibi düşünmeyen Müslümanları genellikle sapıklık ve küfürle itham etmiş ve müntesiplerini bu anlayış üzere yetiştirmişlerdir. ${ }^{63}$ Abdullah Enes'in bildirdiğine göre, 1980'li yılların ikinci yarısında Afganistan sahası İslam Dünyası'nın değişik yerlerinden gidenler için tanışma, tartışma ve hatta çatışma alanına dönüşmüştü. Ülkelerinde gördükleri bask1 ve işkenceler sonucu bilenmiş olan şiddet yanlıları için Afganistan ortamı adeta bir patlama ve içlerini dökme sahasıydı. Şiddet yanlısı bu akımlara mensup kişiler "hâkimiyet", "velâ-berâ", "cihad" ve "tekfir" gibi temel konular etrafinda dile getirdikleri düşüncelerini çok sert bir şekilde savunuyor ve farklı düşüncelere asla müsamaha göstermiyorlard1 $1{ }^{64} \mathrm{Hatta}$ kendileri gibi düşünmeyen diğer radikal akım mensuplarını tekfir etmekten bile çekinmedikleri nakledilmiştir. ${ }^{65}$

Arap Yarımadası'ndan Afganistan'a giden zahirî (lafizcı) Selefî bakış açısıyla mezc olan ve Mısır dönemine nispetle daha katı bir tutum takınan bu akımlara göre bir savaşın kazanılması için Allah yolunda ve küffara karşı yapılıyor olması yeterliydi. Düşmana karşı başlatılması düşünülen herhangi bir savaştan/çatışmadan önce muhtemel sonuçlar ele alınarak savaşın durdurulması doğru değildi. ${ }^{66}$ Çünkü Allah'ın (c.c.) vaadi ${ }^{67}$ gereği zafer her halükarda inananların ve onun yolunda mücadele edenlerin olacaktı. ${ }^{68} \mathrm{Bu}$ anlayıştan hareketle, Ruslara karşı yapılan Celâlâbad Savaşı'nda (1988) muhtemel sonuçlar yeterince dikkate alınmadığ 1 ve gerekli hazırlıklar tam olarak yapılmadığı için birçok mücahidin şehit olmasına sebebiyet verildiği söylenmektedir. ${ }^{69} \mathrm{Bu}$ akımların tedbir almayı ve sebepler çerçevesinde hareket etmeyi hafife alması, düşünce ve fikıh dünyalarının ne denli yüzeysel ve Allah'ın yeryüzüne koyduğu kanunlar ${ }^{70}$ anlamaktan ne kadar uzak olduklarını göstermektedir. Afganistan'da temeli atılan bu şedid akımlar 2000'li yıllarda ve sonrasında büyük oranda Irak ve Suriye' de temerküz etmiştir. ${ }^{71}$ Irak'ta toplanan aşırılık ve şiddet yanlılarının Irak'ta Amerikan işgaline karşı direnen yerli direniş gruplarının tasfiyesinde önemli rol oynadıkları konusunda ciddi iddialar mevcuttur. ${ }^{72}$

63 Kumeyl et-Tavîl, el-Kâide ve ehavâtuha, Beyrut, Dâru's-sâkî, 2007, s. 53.

64 Abdullah Enes, Vilâdetu'l-Afğani'l-Arap, Beyrut, Dâru's-sâkî, 2002, s. 36.

65 Mevlâ, a.g.e., s. 690.

66 Mustafa Hamid, Lia Varal, a.g.e., s. 281.

67 Nisâ, 4/141.

68 Mustafa Hamid, Lia Varal, a.g.e., s. 280.

69 Mustafa Hamid, Lia Varal, a.g.e., s.149.

70 Ahzab, 62.

71 Mustafa Hamid, Lia Varal, a.g.e., s.281.

72 Ahmet Abdu Rabbih, Muhammed Muhtar Kandîl, el-Fikru'l-İslâmî el-cihâdî el-Muasır, Kahire, Dâru'l-merâyâ, 2016, s. 384; Mustafa Hamid, Lia Varal, a.g.e., s. 285. 
Radikal akımlar Afganistan'da oldukları dönemde Cezayir'de parlamento seçimleri yapıldı. 29 Aralık 1991'de yapılan seçimleri İslami Kurtuluş Cephesi kazand1. Ancak İslami Kurtuluş Cephesi 11 Ocak 1992'de askerî bir darbeyle iktidardan uzaklaştırıldı ve önde gelen birçok adamı tutukland1. ${ }^{73}$ Askeri darbe ve tutuklamaların ardından yoğun gösteriler başladı ve ülkede ciddî karışıklıklar çıkt1. Bu karışıklıkları firsat bilen Cezayirli şiddet yanlıları Afganistan'dan Cezayir'e döndüler ve rejime karşı silahlı mücadele başlattılar. ${ }^{74}$ Şiddet yanlılarının Cezayir'de de Afganistan'daki ayrıştırıcı tavırlarını sürdürdükleri ve kendileriyle aynı fikre sahip olmayan insanları -rejime karşı olsalar bile- tekfir ederek öldürdükleri söylenmektedir. ${ }^{75}$ Yaptıkları açıklamaların ve eylemlerin sonuçlarını dikkate almayan bu akım açıklamalarıyla ve eylemleriyle bütün dünyayı karşılarına aldılar ve adeta İslami Kurtuluş Cephesi'ni istemeyen Batının ekmeğine yağ sürdüler. Bunların yaptığı olumsuzluklar ve terör eylemleri Cezayir'deki bütün İslamcılara mal edildi ve düşmanlarını çoğaltmaktan başka bir işe yaramadı. Zamanla Cezayir'deki İslamcılar çoğu Batılılar tarafından, hak arayan bir kitle olmaktan ziyade bütün dünyaya tehditler savuran bir terörist yapı olarak görülmeye başlandı. ${ }^{76}$

Cezayir'deki bu radikaller şiddet içerikli fikirlerini benimseyen herkesi kendi gruplarına aldılar. Kısa zaman sonra daha önce İslâmî camia tarafından hiç tanınmayan bir takım insanlar grup içerisinde yönetici konumuna yükseldi ve birçok vahşi eyleme imza attılar. ${ }^{77}$ Kumeyl et-Tavîl'in bildirdiğine göre, "Cezayır'deki şiddet yanlıları tekfirde ve kan dökmede o kadar aşırıya gittiler ki, Afganistan'da Ruslara karşı yıllarca savaşmış tecrübeli bazı mücahitler Cezayir'deki iç çatışmaları durdurmak için girişimde bulununca, kâfir rejimle görüşme yaptıkları ve Müslümanların davasını sattıkları gerekçesiyle onları dahi tekfir edip öldürdüler." ${ }^{78}$ Şiddet yanlısı bu akım emniyet birimlerinde ve devlet kademelerinde çalışanların evlerinin basılabileceği ve evde bulunan çoluk çocuğun öldürülebileceği fetvasını yayınladılar ve bu fetva doğrultusunda eylemler yaptılar. Bu tür fetvalarda ve eylemlerde en güçlü desteği 1990'l1 yıllardan günümüze kadar şiddet yanlısı akımların ileri gelen yazarlarından ve öncülerinden olan Ebû Katâde el-Filistînî'den aldılar. ${ }^{79}$

73 Kumeyl et-Tavîl, el-Hareketü'l-İslamiyye el-müselleha fi'l-Cezâir, Beyrut, Dâru'n-nehâr li'nneşr, 1998, s. 96.

74 Tavîl, a.g.e., s. 59-60.

75 Mevla, a.g.e., s.712.

76 Tavîl, a.g.e., 197-198.

77 Tavîl, a.g.e., s. 193.

78 Tavîl, a.g.e., s. 228.

79 Tavîl, a.g.e., s. 228. Ebû Katâde el-Filistînî müstear ismiyle tanınan bu kişinin asıl ad1, Ömer 
Müslüman halkın başına açacağı bela ve musibetler düşünülmeden verilen bu tür fetvalar ve gerçekleştirilen eylemler o günlerde Cezayir'de firsat kollayan dâhili ve harici bazı gizli mihrakları harekete geçirdi. İstihbarata ve Emniyet birimlerine yerleşmiş bir takım güçler, başta Fransa olmak üzere Batı'nın desteğini alarak Cezayir'de biriken İslâmî gücü tamamen kırmak için Müslüman halka yönelik akla hayale gelmeyecek zulümler ve kanlı eylemler gerçekleştirdikleri ifade edilmektedir. ${ }^{80} \mathrm{O}$ dönem bir müddet Cezayir istihbaratında çalışan ve daha sonra Cezayir'i terk ederek Fransa'ya yerleşen Habîb Süveydiyye adlı subayın beyanına göre, Cezayir istihbaratı bir noktadan sonra artık sadece rejime karşı silahlı mücadele verenleri değil, İslami Kurtuluş Cephesi'ne oy verdiğini tahmin ettikleri herkesi tutuklamaya başlamış ve hatta bazı özel istihbarat birimleri aşırılık yanlısı kimselerin kılık kıyafetine bürünerek İslami Kurtuluş Cephesi'nin yüksek oy aldığı bazı mahallelere gece baskınları düzenleyerek yüzlerce masumu katletmiştir. ${ }^{81}$

15 Şubat 1989'da Ruslar Afganistan'dan çekildi. Bu gelişmeyi takip eden yıllarda şiddet yanlısı grupların büyük bir kısmı ülkelerine geri döndü. Afganistan'da yaptıkları hazırlık ve plan doğrultusunda, kendi ülkelerine dönen bu gruplar yeniden rejimlere karşı silahlı mücadeleye başladılar. Cezayir ve Mısır başta olmak üzere Libya, Yemen ve Suudi Arabistan'da birçok silahlı ve bombalı eylem gerçekleştirdiler. Sonuçlarını dikkate almadan gerçekleştirdikleri bu eylemler hem kendilerine hem de İslâmî çalışmalara ciddi manada zarar verdi. ${ }^{82}$ Şiddete dönük söylemleri ve eylemleri sebebiyle toplum içerisinde de kendilerine yer bulamayan bu gruplar yeniden Afganistan'a dönmenin yollarını aramaya başladılar. Bu arada Taliban hareketi diğer Afgan mücahit gruplarıyla savaşarak 1996 yılında Afganistan'ın çoğunu ele geçirmiş ve Molla Ömer liderliğinde İs-

Mahmud Osman'dır. 1960 yılında Filistin'de doğmuştur. Üç yaşında ailesi ile beraber Ürdün’e taşınan el-Filistînî, Üniversite eğitimi dâhil bütün eğitimini Ürdün'de tamamlamıştır. 1990'lı yılların başında Afganistan'a gitmiş ancak orada fazla kalmayarak İngiltere-Londra'ya geçmiştir. Londra'da kaldığı yıllarda Cezayir'deki şiddet yanlısı Selefîlerin fetva makamı gibi çalışmıştır. 2001-2013 yılları arasında Londra'da hapis yatan el-Filistînî, 2013 yılında İngiltere tarafından Ürdün'e teslim edilmiştir. Şuan Ürdün'de yaşamakta olan el-Filistînî şiddet yanlısı Selefîlerin en etkin yazarlarından ve öncülerindendir. Geniş bilgi için bkz. Ahmed Abdu Rabbih, Muhammed Muhtâr, a.g.e., s.400-402.

80 Mevlâ, a.g.e., s. 712; O dönem Cezayir istihbaratında çalışan ve bu tür katliamları gerçekleştiren bir biriminde görevli olan bir subayın itirafları için bkz. https://youtu.be/3oe3Q751s1Q, (Erişim tarihi, 29. 11. 2017)

81 Geniş bilgi için bkz. Habîb Süveydiyye, el-Harbu'l-kazirah, Dımeşk, Verd li’t-tıbâati ve'nneşr ve't-tevzi, 2003, s. 95-168.

82 Tavîl, a.g.e., s. 265-266. 
lâmî bir emirlik kurduğunu ilan etmişti. ${ }^{83} \mathrm{Bu}$ yeni gelişme radikal grupların Afganistan’a dönüşünü hızlandırdı. Böylece şiddet yanlıları için ikinci Afganistan dönemi başlamış oldu. Rusların çekilmesinin ardından Afganistan'dan Sudan'a giden Üsame b. Ladin ve arkadaşları da o yıllarda Sudan'dan Afganistan'a döndüler. Bin Ladin, Afganistan'a dönüşünün ardından Taliban lideri Molla Ömer'e biat ettiğini ilan etti ${ }^{84}$ ve Afganistan'a dönen radikal grupları el-Kâide adı altında örgütlemeye başladı. ${ }^{85}$

Bin Ladin Afganistan'a ulaştıktan kısa bir süre sonra el-Kâide adına Amerika başta olmak üzere Batı aleyhine medyaya sert demeçler vermeye başladı. ${ }^{86} \mathrm{Bin}$ Ladin'in Amerika'ya ve Batı'ya karşı meydan okuyuşu, 26 Mayıs 1998'de "Yahudi ve Hıristiyanlara Karşı Küresel İslami Cihad Cephesi” kurduğunu ilan etmesiyle zirveye ulaşt1. ${ }^{87}$ Taliban Hareketi diğer Afgan mücahit gruplara karş1 şiddet kullanan bir hareket olduğu halde, Bin Ladin'in Batı'ya karşı meydan okumasından ve şiddet dili kullanmasından rahatsızlık duyduğu söylenmektedir. ${ }^{88}$ Bin Ladin'in Amerika'ya ve Batı'ya karşı sert söylemlerinin atmosferinde Amerika'da 11 Eylül hadisesi gerçekleşti. 11 Eylül 2001'de Amerika'nın küresel ekonomik gücünü temsil eden Dünya Ticaret Merkezi ve yine Amerika'nın askeri gücünü temsil eden Pentagon uçaklarla vuruldu ve Dünya Ticaret Merkezi (İkiz Kuleler) çöktü. 11 Eylül eylemlerini Amerika'nın bilgisi ve göz yummasıyla el-Kâide'ye bağlı örgüt elemanlarının gerçekleştirdiği görüşünü savunanlar ${ }^{89}$ olduğu gibi, bu eylemleri el-Kâide'nin yapmadığını iddia edenler de vardır. ${ }^{90}$ İncelediğimiz konu itibariyle bizi burada ilgilendiren Bin Ladin'in el-Kâide örgütü adına bu eylemi kameralar karşısında açık bir şekilde üstlenerek ${ }^{11}$ Afganistan başta olmaz üzere İslam Dünyası'nın başına büyük felaketler açılmasına sebebiyet vermesidir. 11 Eylül saldırılarını bahane eden Amerika artık beklediği kozu eline geçirmişti. Asker-sivil ayırımı yapmadan Afganistan'a yönelik hava akınları düzenlemeye

83 Mevla, a.g.e., s.701.

84 Allûş, a.g.e., s. 28.

85 Mevla, a.g.e., s.713.

86 Mustafa Hamid, Lia Varal, a.g.e., s.204.

87 İbrahim b. Salih el-Âyid, et-Tekfîr inde cemâati'l-unf el-muâsır, Beyrut, Merkezu Nemâ li'lbuhûs-i ve'd-dirâsât, 2014, s. 81.

88 Mustafa Hamid, Lia Varal, a.g.e., s. 205.

89 Jason Burge, el-Kâide Terörün Gölgesinde, trc. Ebru Kılıç, İstanbul, Everest Yayınları, 2004. s. 30 .

90 https://www.sasapost.com/11-september-2001-world-trade-center/. (Erişim tarihi, 12. 5. 2019.)

91 https://youtu.be/nJPiByBY4Qk (Erişim tarihi, 16. 5. 2019.) 
başladı. ${ }^{92}$ Artık Amerika İslam Dünyası'na yönelik yıllarca sürdüreceği bir savaşı başlatmışt. ${ }^{93}$ Amerika'nın saldırıları sonucu Afganistan'da binlerce insan öldü, binlerce insan da yaralandı. Halkın birçoğu yerini-yurdunu terk ederek başka şehirlere göçmek zorunda kaldı. ${ }^{94} 11$ Eylül eylemleri sonrası Amerika'nın İslam Dünyası'na saldırısı sadece Afganistan ile sınırlı kalmadı. Irak'ta kimyasal silahlar olduğu bahanesiyle 20 Mart 2003'te Irak'a girdi. Kısa sürede Irak'1n birçok kentini işgal ederek ülkenin yer altı ve yer üstü kaynaklarına el koydu ve on binlerce insan öldürdü. Amerika Irak işgalinden sonra Suudi Arabistan ve Körfez Ülkeleri başta olmak üzere Ortadoğu'daki varlığını daha çok hissettirmeye başladı. Batı'da ve İslam Dünyası'nda İslâmî çalışmalar ve yardım faaliyetleri yakın takibe alındı ve Müslümanlar ciddi sorunlarla karşı karşıya kaldılar. ${ }^{95}$

\subsection{Amerika'nın Irak İşgali ve Şiddet Yanlısı Radikal Akımların Irak’ta Toplanması}

2 Ekim 2001'de Amerika'nın Afganistan'a hava operasyonu başlatmasıyla şiddet yanlısı radikal akımlar büyük oranda Afganistan'ı terk etmeye başladılar. Afganistan'1 terk eden şiddet yanlısı gruplardan biri Ebu Mus'ab ez-Zerkâvî'nin öncülügüünde İran üzerinden Irak’a gitti. ${ }^{96} 20$ Mart 2003’te Amerika müttefikleriyle beraber Irak'a saldırdı. Irak Ordusu'nun dağılmasının akabinde Irak Sünnîlerinin başını çektiği çeşitli gruplar Amerikan işgaline karşı direniş başlattı. ${ }^{97}$ Zerkâvî öncülüğündeki şiddet yanlısı radikaller de Iraklı direniş gruplarından destek alarak işgalcilere karşı direnişe başladı. ${ }^{98} 2003$ 'ün sonlarına doğru direnişin şiddetlenmesi üzerine Irak’ta tecrübeli savaşçılara ve maddî desteğe ihtiyaç arttı. Bu desteği bulabilmek için daha önce (Afganistan'da) Bin Ladin'e biat etmemiş olan Zerkâvî, Bin Ladin'e biat ettiğini açıladı. ${ }^{99}$ Zerkâvî, Bin Ladin'in desteğini aldıktan sonra, Afganistan başta olmak üzere, Çeçenistan, Bosna Hersek ve Keş-

92 Abdulbari Atvan, Mâ ba 'de Bin Ladin el-Kaide el-cîlu 't-tâlî, Beyrut, Dâru's-sâkî, 2013, s. 2122.

93 Hamâde, a.g.e., s. 20.

94 Hasan İbrahim ed-Duğaym, el-Ğuluvvu's-siyâsî, İstanbul, Ru'ye li’s-sekâfeti ve'l-i'lâm, 2018, s. 124.

95 Duğaym, a.g.e., s. 125.

96 Abdulbari Atvan, ed-Devletül-İslamiyye, el-cuzûr et-tevehhuş el-müstekbel, 3. bs., Beyrut, Dâru's-sâkî, 2015, s. 95.

97 Necati Alkan, El-Kaide'den Işid'e Din, Şiddet ve Terörizm, Ankara, Karınca Yayınları, 2016, s. 164.

98 Atvan, a.g.e., s. 96.

99 Hasan Ebû Heniyye, Muhammed Ebû Rummân, Tanzîmu'd-devleti'l-İslâmiyye, 2. bs., Amman, Friedrich Ebert, 2015, s. 35. 
mir gibi cihat bölgelerinde savaşmış deneyimli kişilerle irtibat kurarak bunların önemli bir kısmını Irak'a getirtmeyi başardı. ${ }^{100}$ Abdulbârî Atvan'a göre, Zerkâvî ve adamlarının işgalcilerin yanı sıra Şiîleri de hedef almaları, Irak işgalinden sonra bazı Şiî partiler ve milis gruplar tarafından dışlanan Sünnî aşiretlerden ve İran korkusu yaşayan bazı Arap ülkelerinden de destek bulmalarına yardımcı olmuştur. ${ }^{101}$ Zerkâvî, elde ettiği bu yardımlarla kısa sürede ciddi bir güce ulaştı̆̆ 1 ve 2004 yılının sonlarına gelindiğinde şiddet yanlısı radikal akımları Irak’ta büyük oranda örgütlediği söylenmektedir. ${ }^{102}$

Amerika'nın Irak'a girmesinden yaklaşık beş ay sonra, işgale karşı daha iyi mücadele verebilmek için Sünnî direniş grupları bir araya gelerek kendi aralarında bir ittifak oluşturdular. Ancak Zerkâvî ve benzeri şiddet yanlıları aşırı ve sert görüşleri nedeniyle bu oluşumda yer almadılar. Bunlar Afganistan'daki ayrılıkçı tavırlarını devam ettirerek ayrı bir oluşuma gittiler ve 2005 Aralık ayında kendilerine yakın gördükleri gruplarla "Mücahitlerin Şûrâ Meclisi" adında bir ittifak kurduklarını ilan ettiler. ${ }^{103}$ Irak'taki radikal gruplar bu oluşumla Sünnî direniş cephesinde ilk çatlağı oluşturmuş oldular. O gün direnişçilerin safını ikiye bölen bu gruplar, daha sonraki yıllarda Irak ve Suriye'de Müslümanlara ciddî sıkıntılar yaşatan DEAŞ'1 kuran gruplar olduğu iddia edilmektedir. ${ }^{104}$

Zerkâvî ve beraberindeki şiddet yanlısı gruplar sadece kendi İslam anlayışlarının doğru olduğu ve hakikati kendilerinin temsil ettiği inancıyla hareket ederek işgalcilerin ve Şiîlerin yanı sıra zamanla kendi anlayışlarını benimsemeyen Sünnî direniş gruplarını da hedef aldılar. Takındıkları tavırlarında ve ortaya koydukları eylemlerinde muhtemel sonuçları dikkate almayan ve yaptıkları işin nereye varacağını düşünmeyen bu akım, direniş gruplarıyla savaşarak direniş cephesini zayıflatmış ve işgalcilerin işini kolaylaştırmıştır. 7 Haziran 2006'da Amerikan işgal kuvvetleri tarafindan gerçekleştirilen bir hava bombardımanında Zerkâvî öldürüldü. Zerkâvî'nin öldürülmesi üzerine el-Kâide lideri Bin Ladin'in onayıyla Irak kökenli Ebû Ömer el-Bağdâdî akımın genel emirliğine, Ebû Hamza el-Muhacir ise askerî kanat sorumluluğuna getirildi. ${ }^{105}$ Zerkâvî sonrasında da zayıflamış olan direniş gruplarını ve kendilerine itiraz edenleri hedef almaya devam eden şiddet yanlıları zamanla Sünnî bölgeleri iç savaşa sürükledi. Asker ve polis topla-

100 Atvan, a.g.e., s. 99.

101 Atvan, a.g.e., s. 99.

102 Atvan, Mâ ba'de Bin Ladin el-Kaide el-cîlu't-tâlî, s. 16

103 Muhammed Muhtar Kandîl, a.g.e., s. 384.

104 Muhammed Muhtar Kandîl, a.g.e., s. 384.

105 Tavîl, el-Kâide ve ehavâtuha, s. 365. 
ma merkezlerine, karakollara ve devlet müesseslerine yönelik birçok intihar eylemi düzenlediler. Bu eylemlerde yüzlerce insan öldü ve binlercesi yaralandı. ${ }^{106}$ Abdulbârî Atvan'ın bildirdiğine göre, bunlar muhaliflerine karşı o kadar ileri gittiler ki, siyasete girmeye, seçimlere katılmaya ve hükümette görev almaya cevaz veren âlimleri ve liderleri dahi öldürdüler. Ayrıca Zerkâvî zamanında başlayan kameralar karşısında insanların kafasını kesme ve benzeri vahşi eylemler Zerkâvî sonrası artarak devam etti. ${ }^{107} \mathrm{Bu}$ vahşi eylemleri bütün dünya basın-yayın arac1lığıyla izledi ve İslam düşmanları bu vahşi eylemleri İslam'a ve Müslümanlara mal etmeye çalıştı.

19 Nisan 2010'da Ebu Ömer el-Bağdâdî ve askerî işler sorumlusu Ebu Hamza el-Muhacir bir hava bombardımanında öldürüldü. Örgütün tepesindeki önemli iki liderin ani ölümü üzerine toplanan Şûrâ Meclisi Ebû Bekir el-Bağdâdî’ye biat ettiklerini açıkladılar. ${ }^{108}$ Bağdâdî örgütü toparlamak için ciddi bir çalışma içerisine girdi. Örgütün Sünnîlerin desteğiyle güçlenebileceğini düşünen Bağdâdî, Sünnîlerin desteğini alma konusunda tehdit ve şiddet dâhil her yolu denedi. Öyle ki, çoğu zaman işgalcilerden ve Şiîlerden çok kendilerini desteklemeyen ve eleştiren Sünnîlerle savaştı. ${ }^{109}$ Bağdâdî döneminde şiddet o kadar arttı ki, söz konusu akımın düzenlediği eylemler sebebiyle Irak'ta her gün onlarca insan hayatını kaybetmeye başladı. Artık Iraklı siviller, camilerde ve pazaryerlerinde hedef alınır ve toplu katliamlara maruz kalır hale geldiler. ${ }^{110}$

Daha çok Sünnî bölgelere saldırarak oraları ele geçirmeye öncelik veren şiddet yanlısı bu akım Fellûce, el-Enbâr, Rakka, Crablus ve Deyruzzûr gibi önemli şehirleri ele geçirdi. Bağdâdî 9 Nisan 2013'te hem Irak hem de Suriye'deki varl1ğını pekiştirmek için “Irak Şam İslam Devleti”ni (DEAŞ) ${ }^{111}$ ilan etti. ${ }^{112}$ DEAŞ 11 Haziran 2014'te Irak'in en büyük ikinci şehri olan Musul'u ele geçirdi. ${ }^{13}$ Musul'u

106 Fuad Hüseyin, a.g.e., s.74.

107 Atvan, a.g.e., s. 277.

108 Ahmed Salah Osman, Halil el-Kâdî, Mâ lem yükteb an Dâiş ru'ye mine'd-dâhil...el-hataru'l-kâdim, Beyrut, Dâru Eb‘âd, 2015. s. 64.

109 Atvan, a.g.e., s. 276.

110 Geniş bilgi için bkz. Atvan, ed-Devletül-İslamiyye, el-cuzûr et-tevehhuş el-müstekbel, s. 277.

111 “Irak Şam İslam Devleti”nin kısaltılmış şekli Türkiye'de ilk zamanlar “IŞiD” olarak kullanıld. Ancak 11 Aralık 2015’ten itibaren Dışişleri Bakanlığı'nın genelgesi esas alınarak "DEAŞ" olarak değiştirildi. Bizde çalışmamızda bu genelgeye uygun olarak "DEAŞ” kısaltmasını kullandık. Bkz. T.C. Başbakanlık Diyanet İşleri Başkanlığı Din İşleri Yükssek Kurulu başkanlığg, Dini İstismar ve Tedhiş hareketi DEAŞ, Ankara, 2016. s. 1, dipnot, 1.

112 Ahmed Salah Osman, Halil el-Kâdî, a.g.e., s. 62.

113 Esad el-Azzûnî, Dâiş en-neş'etu ve't-tavzîf, Amman, Dâru Dicle, 2015, s. 17. 
ele geçirdikten kısa bir süre sonra DEAŞ'ın adamları 30 Haziran 2014'te (sözde) "Hilafet Devleti”nin kurulduğunu ilan ettiler. Hilafet ilanından beş gün sonra da (5 Temmuz 2014) Bâğdâdî Musul'daki el-Câmiu'l-Kebîr'de (Büyük Cami) Cuma hutbesi okuyarak, Müslümanların halifesi seçildiğini ve bütün Müslümanların kendisine itaat etmesi gerektiğini açıkladı. ${ }^{114}$ Şiddet yanlısı bu akım (sözde) hilafet ilanının akabinde iyice sertleşti ve kendisini Müslümanların tek devleti ve kurtarıcısı görmeye başladı. Gelinen noktada Bağdâdî ve adamları yaptıkları açıklamalarla bütün dünya Müslümanları adına konuşmaya ve yakında Roma'yı da fethedecek bir eda ile bütün dünyaya meydan okumaya başladılar. ${ }^{115}$

Hilafet ilanından sonra Bağdâdî’nin başında bulunduğu şiddet yanlısı akım kendi hâkimiyetini tesis etme yolunda bir devlet refleksiyle hareket ederek kendilerine karşı gelenleri ve eleştirenleri acımasızca ve aleni olarak cezalandırmaya başladılar. Esirlerin ve muhaliflerin kafalarını kesme, karşıtlarını topluca kurşuna dizme, kent merkezlerinde insanların gözü önünde idam etme, ateşle yakma, suda boğma, yüksek binalardan aşağıya atma gibi çeşitli cezalandırma sahneleri kameralar tarafindan kaydedilerek bütün dünyaya servis etme adet haline geldi. ${ }^{116}$ Gelinen noktada halifeye biat etmeyen ve söz konusu akımı eleştiren kim olursa olsun tereddütsüz infaz ediliyor ve şiddet kutsanıyordu. Uyguladıkları şiddeti din adına uyguladıklarını iddia ediyor ve kendilerince bir takım dinî referanslara dayandıklarına inanıyorlard. ${ }^{117}$

Necati Alkan'ın da ifade ettiği gibi, Irak ve Suriye merkezli vahşet saçan bu akım belirsizlik üzerine kurulmuştu. Özellikle Bağdâdî döneminde akım içerisinde daha önce tanınmayan kişilerin etkinlikleri ciddi manada artmıştı. Akımı yönlendirenlerin çoğu tanınmayan, bilinmeyen müstear isimli şahıslardan oluşuyordu. Bu meçhul şahısların öncülüğünde bölgede adeta bir korku imparatorluğu kuruldu. ${ }^{118}$ Çocuk yaştaki insanların ellerine silahlar tutuşturularak onlara infaz seansları uygulatıldı. İnfazına karar verdikleri Müslümanların son kez namaz k1lıp dua etme isteklerine dahi izin vermeyerek tarihte görülmemiş vahşi uygulamalara imza attılar. ${ }^{119}$ Es'ad el-Azzûnî'ye göre, İsrail'e bir taş dahi atmayan bu akım Batılı birçok istihbarat örgütü tarafından istenilen hedefe doğru yönlendi-

114 Hasan Ebû Heniyye, Muhammed Ebû Rummân, a.g.e., s. 239.

115 Atvan, a.g.e., s. 69-70.

116 Azmi Bişâre, Tanzîmu'd-devle el-mükennâ Dâiş, Beyrut, el-Merkezu'l-Arabî li'l-ebhâs ve dirâsâti's-siyâsât, 2018, s. 217.

117 Atvan, a.g.e., s. 69.

118 Alkan, a.g.e., s. 171.

119 Mecmûatun mine'l-kuttâb, Kâlû a 'n devleti'l-Bâğdâdî, Ketâibu red'i'l-hâvâric, b.y.y., 2015, s. 27. 
rildi. Bu hedef, Ortadoğu'daki İslâmî birikimin vurulması, İslam Dünyası'nda tam olarak ele geçirilemeyen kaynakların ele geçirilerek sömürülmesi ve İsrail'in bölgedeki nüfuzunu artırarak ömrünü uzatmakt1. ${ }^{120}$

\section{Sonuç}

İslam fikhında 'muhtemel sonuçların dikkate alınmasını' ifade eden i'tibâru'l-meâlât kâidesi Kur'an ve Sünnet ile sabit olup, sahabe döneminden itibaren Müslümanlar tarafından dikkate alınmış, verilen fetvalarda ve ortaya konulan eylemlerde bu kâideye büyük bir ciddiyetle riayet edilmiş̦tir. i'tibâru'l-meâlât kâidesine, İslam'ın temel iki kaynağında vurgu yapılması, İslam tarihi boyunca bu kâidenin Müslümanlar tarafından büyük bir ciddiyetle uygulanması ve kadim ulemanın bu kâidenin ifade ettiği mana ve maksadı çeşitli tabirlerle ifade etmesi, şüphesiz bu kâidenin önemine ve İslam ahkâmı içerisinde kullanım alanının genişliğine işaret etmektedir. $\mathrm{Bu}$ denli önemli olmasına rağmen şiddet yanlısı akımlar, i'tibâru'l-meâlât kâidesini dikkate almamış, Müslümanların maslahatı için çalıştıkları iddialarını, eylemlerinin meşruiyeti için yeterli görmüştür. i'tibâru'l-meâlât kâidesi İslam tarihi boyunca âlimler tarafından 'bireysel' meselelerde dahi nazar-1 itibara alındığ 1 halde, şiddet yanlısı akımlar bu kâideyi 'geniş toplumları' ilgilendiren meselelerde bile nazar-1 itibara almayarak toplumları felakete sürüklemişlerdir. Mısır, Afganistan, Cezayir, Irak ve Suriye başta olmak üzere dünyanın değişik yerlerinde gerçekleştirdikleri eylemlerde muhtemel sonuçlarını dikkate almadıkları için Müslüman toplumların başına telafisi mümkün olmayan felaketler açmış, saçma sapan söylemleri ve eylemleri sonucu binlerce masum insan ölmüş, binlercesi sakat kalmış ve şehirler harap olmuştur.

Savundukları fikirlerin ve yaptıkları açıklamaların ne tür sonuçlar ortaya çıkaracağını dikkate almadan hareket eden şiddet yanlıları, ilk olarak mevcut rejimlerde yönetici konumda olan bütün Müslümanları -maksadına ve niyetine bakmaksızın- 'tekfir' ettiler. Bu akımın İslâmî esaslara dayanmayan tekfir anlayışı zamanla, siyasete atılan ve hatta seçimlerde oy veren Müslümanları da kapsayacak şekilde genişledi. Fikirlerini yayma hususunda karşılaştıkları olumsuzluklar sebebi ile iyice sertleşen bu insanlar gelinen noktada kendileri gibi düşünmeyen ve kendilerini desteklemeyen bütün Müslümanları tekfir edip öldürmeye başladılar. Hatta Afganistan, Irak ve Suriye'de işgalcilere karşı omuz omuza cihat ettikleri mücahit arkadaşlarını bile -kendileri gibi düşünmedikleri ve düşmanla işbirliği yaptıkları gerekçesiyle- tekfir edip öldürdüler.

120 Geniş bilgi için bkz. Es'ad el-Azzûnî, Dâiş: Tanzîmu echizeti muhâberâti'd-düvel ve leyse Tanzîmu'd-Devleti'l-İslâmiyye, Amman, Dâru Dicle, 2016, s. 7-8. 
Şiddet yanlısı bu akımların mensupları kendi anlayışlarının ve metotlarının tek doğru olduğuna inandıkları için, kendilerine katılmayan bütün İslâmî cemaat ve cemiyetlere karşı düşmanca bir tutum içine girdiler. Şüphesiz onların bu tutumlarında, bu yapıları kendilerine rakip olarak görmeleri de etkili olmuştur. Kendilerini diğer İslâmî yapılardan farklı addeden bu akım mensupları kadim Hâricîler gibi, sürdürülebilirliğini düşünmeden, kendilerine ait bir bölge oluşturup emirlik ya da devlet ilan etme yoluna gittiler. Hâricî ve dışlayıcı bir zihniyete sahip olan bu akımlar, geldiği nokta itibariyle bir başarı elde edemedikleri gibi, başlangıçta toplumda oluşturdukları sempatiyi de kaybetmekle karşı karşıya kaldılar.

İslam'ı yüceltmek adına ortaya çıktığını iddia eden bu akımlar, cihad adı altında ortaya koydukları vahşi uygulamalarla İslam'1, kafa-kol kesen, rastgele öldüren, yakıp-yıkmayı emreden bir din gibi göstermiştir. Vahşet içeren eylemler ve görüntüler Müslüman olamayan geniş bir kesim nezdinde İslam'ın imajına da zarar vermiştir. Yaygın kitle iletişim araçları aracılığıyla kendi propagandalarını başarılı bir şekilde yapan bu akımların eylemleri, İslam'ın, Müslüman olmayanlara hayat hakkı tanımayan bir din olarak algılanmasına yol açmıştır. Bu akım gerek kendilerinin, gerekse uluslararası medyanın vahşet görüntülerini devamlı gündem yapmasıyla bir korku imparatorluğu oluşturmuş ve İslam düşmanlarının eline büyük bir koz vermiştir. Söz konusu akımların bu süreçte sergilediği bütün vahşi uygulamalar İslam'a mal edilmiş ve İslam'ın bir medeniyet dini olmadığı, insanlara vahşetten başka sunacak bir şeyi olmadığı algısını yaygınlaşmıştır. Kitle iletişim araçları üzerinden beslenen bu algı ile insanların İslam'a karşı cephe alması ve İslam' dan uzak durması amaçlanmıştır. Bu akımın sergilediği kanlı eylemler sebebiyle, özellikle İslam Dünyası'nın dışında azınlıklar halinde yaşayan Müslüman toplumlar ciddi tehdit ve zorluklarla karşı karşıya kalmışlardır.

Bütün Müslümanlara kapılarını açtıklarını ilan eden şiddet yanlısı akımın mensupları siyasi basiretten yoksun oldukları ve yaptıkları işlerin sonuçlarının nereye varacağını düşünmedikleri için bölgesel ve küresel çapta farklı odaklar tarafindan kontrol edilen istihbarat örgütleri için kullanışlı bir araca dönüşmüşlerdir. Özellikle Cezayir, Irak ve Suriye başta olmak üzere birçok yerde gizli bir takım mihrakların değişik zamanlarda ve değişik vesilelerle bu insanların içine sızdığ 1 ve bunları kendi çıkarları doğrultusunda kullandığ 1 bilinmektedir. Şiddeti yöntem olarak benimseyen bu akımın mensupları, özellikle Irak ve Suriye döneminde cihad adı altında gerçekleştirdikleri şiddet eylemleriyle İslam Dünyası'na ve Müslümanlara telafisi mümkün olmayan büyük zararlar vermişlerdir. 


\section{Kaynakça}

Abdulbari Atvan, Mâ ba 'de Bin Ladin el-Kaide el-cîlu't-tâlî, Beyrut, Dâru's-sâkî, 2013.

, ed-Devletül-İslamiyye, el-cuzûr et-tevehhuş el-müstekbel, 3. bs., Beyrut, Dâru's-sâkî, 2015.

Abdullah Enes, Vilâdetu'l-Afğani'l-Arap, Beyrut, Dâru's-sâkî, 2002.

Abdulmun'im Munîb, Delîlu'l-harekâti'l-İslâmiyye el-muâsıra, Kahire, Mektebetu'l-medbûlî, 2010.

Ahmed Abdu Rabbih, Muhammed Muhtar Kandîl, el-Fikru'l-İslâmî el-cihâdî el-muâsır, Kahire, Dâru'l-meyârâ, 2016.

Ahmed Mer'î Hasan, Fikhu't-tenzîl, Beyrut, Merkezu Nemâ li’l-buhûsi ve’ddirâsât, 2015.

Ahmed Salah Osman, Halil el-Kâdî, Mâ lem yükteb an Dâiş ru'ye mine'd-dâhil...el-hataru'l-kâdim, Beyrut, Dâru Eb ‘âd, 2015.

Ahmed Salim, İhtilâfu>l-İslâmiyyîn, 2. bs., Beyrut, Merkezu Nemâ li’l-buhûsi ve'd-dirâsât, 2014.

Alkan, Necati, El-Kaide'den Işid'e Din, Şiddet ve Terörizm, Ankara, Karınca Yayınları, 2016.

Aydınalp, Halil, “İslam Dünyasında Siyasi Şiddetin Sosyolojik Unsurları”, Din ve Şiddet, Recep Tayyip Erdoğan Üniversitesi, Ankara, Kalkan Matbaacılık, 2016.

Azmi Bişâre, Tanzîmu'd-devle el-Mükennâ Dâiş, Beyrut, el-Merkezu'l-Arabî li'l-ebhâs ve dirâsâti's-siyâsât, 2018.

Beyzâvî, Nâsıruddîn Ebû Saîd Abdullah b. Ömer, Envâru't-tenzîl ve esrâru't-te 'vîl, Beyrut, Dâru ihyâi't-turâsi'l-Arabî, t.y.

Buharî, Ebû Abdillah Muhammed b. İsmail Sahîhu'l-Buharî, thk. Muhammed Züheyr, Dâru Tavkı'n-necât, b.y.y, 2001.

Cühenî, Mâni' b. Hammâd, el-Mevsûa 'tu'l-müyessere fî'l-edyân ve'l-mezâhib ve'l-ahzâbi'l-muâsıra, 3. bs., Riyad, Dâru'n-Nedveti'l-Âlemiyye, 1997.

Cündî, Enver, Hasan el-Bennâ, Dımeşk, Dâru〉l-kalem, 2000.

Duran, Burhanettin, Y1lmaz, Nuh, “Ortadoğu'da Modellerin Rekabeti: Arap Baharından Sonra Yeni Güç Dengeleri”, Türk Dış Politikası Yıllı̆̆ı, SETA Yayınları, 2011. 
Ebû Şehbe, Muhammed b. Muhammed, es-Sîretu'n-Nebeviyyefídav'il-Kur'ani ve's-Sünne Dimeşk, Dâru'l-kalem, 1992.

Ensârî, Ferîd, el-Mustalahu'l-usûlî, Virjinya, el-Mâ‘hadu'l-Âlemî li'l-fikri'l-İslâmî, 2004.

Esad el-Azzûnî, Dâiiş en-neşetu ve't-tavzîf, Amman, Dâru Dicle, 2015.

, Dâiş: Tanzîmu echizeti muhâberâti'd-düvel ve leyse Tanzîmu'd-Devleti'l-İslâmiyye, Amman, Dâru Dicle, 2016.

Feyyûmî, Ahmed b. Muhammed b. Ali, el-Misbâhu'l-münîr, Beyrut, Mektebetü Lübnan, 1990.

Fuad Hüseyin, Zerkavi el-Kâide'nin İkinci Kuşă̆g, trc. Defne Bayrak, İstanbul, Küresel Yayınları, 2014.

Habîb Süveydiyye, el-Harbu'l-kazirah, Dımeşk, Verd li't-tıbâati ve'n-neşr ve't-tevzi, 2003.

Hasan Ebû Heniyye, Muhammed Ebû Rummân, Tanzîmu'd-Devleti'l-İslâmiyye, 2. bs., Amman, Friedrich Ebert, 2015.

Hasan İbrahim ed-Duğaym, el-Ğuluvvu 's-siyâsî, İstanbul, Ru'ye li’s-sekâfeti ve'l-i'lâm, 2018.

İbn ebî Şeybe, Musannef İbn Eb̂̂ Şeybe, thk. Muhammed Avvâme, Dâru'l-kıble, b.y.y., 2006.

İbn Fâris, Ebu'l-Hüseyn Ahmed b. Fâris, Mu 'cemu mekâyîsi'l-luğa, thk. Abdüsselam Muhammed Harun, Kahire, Dâru'l-fikr, 1979.

İbn Hişâm, Ebû Muhammed Abdu'l-Melik, es-Sîretu'n-Nebeviyye, Kahire, Dâru ihyâi'l-kütübi'l-Arabiyye, t.y.

İbn Kayyım el-Cevziyye, Muhammed b. Ebî Bekir, I'lâmu'l-muvakkîn an Rabbi'l-âlemîn, Kahire, Mektebetü'l-külliyyâti'l-ezheriyye, 1968.

İbn Kesîr, İmadu'd-Dîn Ebu>l-fidâ, el-Bidâye ve'n-nihâye, Kahire, Dâru'l-hadîs, 1997.

İbn Manzûr, Ebu'l-Fazl Cemâluddîn Muhammed b. Mükerrem el-İfrîkî, Lisânul-Arab, Beyrut, Dâru Sâdır, t.y.

İbrahim b. Salih el-Âyid, et-Tekfir inde cemâati'l-unf el-muâsır, Beyrut, Merkezu Nemâ li'l-buhûs-i ve'd-dirâsât, 2014.

İzzeddîn b. Abdusselam, Ebû Muhammed, Kavâi'du'l-ahkam fî mesâlihi'l-enâm, Beyrut, Dâru'l-meârif, t.y. 
Jason Burge, el-Kâide Terörün Gölgesinde, trc. Ebru K1lıç, İstanbul, Everest Yayınları, 2004.

Karadâvî, Yusuf, el-İhvanu'l-Müslimûn, Kahire, Mektebetu Vehbe, 1999.

Kennânî, Abdulhalim, Mevsûa 'tu'ş-şuhedâ, Tanta, Dâru'l-beşîr, 1994.

Kumeyl et-Tavîl, el-Hareketü'l-İslamiyye el-müselleha fi'l-Cezâir, Beyrut, Dâru'n-nehâr li'n-neşr, 1998. , el-Kâide ve ehavâtuha, Beyrut, Dâru's-sâkî, 2007.

Mahmud Abdulhalîm, el-İhvânu'l-Müslimûn, Ehdâs sanaati t-tarîh, İskenderiyye, Dâru'd-dâ've, t.y.

Malik b. Enes el-Medenî, Muvatta, thk. Muhammed Mustafa el-A'zamî, Ebû Zaby, Müessesetü Zayid b. Sultan, 2004.

Mecmûatun mine'l-Kuttâb, Kâlû a 'n devleti'l-Bâğdâdî, Ketâibu red'i'l-hâvâric, b.y.y., 2015.

Muhammed Abdusselem Ferac, el-Farîdatu'l-ğaibe,

http://www.alwahabiyah.com/file/Occation/vijename/T-K55-ar.pdf, (Erişim Tarihi, 3. 10. 2019)

Muhammed Allûş, Dâiş ve ehavâtuhâ, Beyrut, Riyâdu'r-reyyis li'l-küküb ve'n-neşr, 2015.

Muhammed Hâmid Ebu'n-Nasr, Hakîkatu'l-hilâf beyne'l-İhvâni'l-Müslimîn ve Abdunnâsır, Kahire, Dâru't-tevzi' ve'n-neşri'l-İslâmiyye, 1988.

Mustafa Hamid, Lia Varal, el-Arap fi harbi Afganistan, Büyük Biritanya, Dâru Heyrest, 2015.

Müslim, Ebû'l-Hasan b. el-Haccac en-Nîysâbûrî, Sahihu Müslim, thk. M. Fuat Abdulbakî, Beyrut, Dâru ihyau't turasil-Arabî, t.y.

Nesâ̂i, Ebû Abdurrahman Ahmed b. Şuayb el- Horasânî, Sünenü'n-Nesâ̂i, Mektebetu Matbuatu'l-İslamiyye, b.y.y., 1986.

Osmânî, Saduddîn, Fikhu'l-meâlât mefhûmuhû ve kavâiduhû, Kahire, Dâru'l-kelim, 2015.

Reysûnî, Ahmed ve Bârût, Cemal, el-į̧tihad, Dımeşk, Dâru'l-fikr, 2000.

Senûsî, Abdurrahman b. Muammer, I' tibâru'l-meâlât ve murââtu netâici 't-tasarrufât, Riyad, Dâru İbni'l-Cevzî, 2003.

S. Sayyid, Fundamentalizm Korkusu, trc. Ebubekir Ceylan, Nuh Y1lmaz, Şükrü Atsızelti, İstanbul, Açılım kitap, 2017. 
Suud el-Mevlâ, el-Cemââtu'l-İslâmiyye ve'l-unf, Dubai, Merkezu'l-misbâr li'd-dirâsâti ve'l- buhûs, 2012.

Şâtıbî, Ebû İshak İbrahim b. Musa el-Lahmî, el-Muvâfakât fì usûli'ş-şeria, thk. Abdullah Dirâz, Beyrut, Dâru'l-Mârife, 2008.

T.C. Başbakanlık Diyanet İşleri Başkanlığı Din İşleri Yüksek Kurulu Başkanlığ1, Dini İstismar ve Tedhiş hareketi DEAŞ, Ankara, 2016.

Üsame Sa'd, Eşref Iyd Anteblî, "Mukaddime” et-Tarîhu'ş-şamil li'l-İhvani’l-Müslimin, İstanbul, Dâru Nida, 2017.

Verdânî, Salih, Mısır'da İslâmî Akımlar, trc. H. Açar, Ş. Duman, S. Turan, 2. bs. İstanbul, Fecr Yayınlar1, 2011.

Yusuf b. Abdullah Ahmeytu, Mebdeu I'tibâri'l-Meâl fi'l-Bahsi'l-Fıkhî, Beyrut, Merkezu Nemâ li'l-Buhûsi ve'd-Dirâsât, 2012.

Zehrânî, Raşid b. Osman, el-Cemaatu'l-cihâdiyye el-muâsıra ve ebrezu kıyâdâtihi'l-fikriyye, Riyad, Dâru Vucûh, 2016.

https://m.facebook.com/story.php?story_fbid=589713864831004\& id $=100013771866578$

https://youtu.be/3oe3Q751s1Q 